NBER WORKING PAPER SERIES

\title{
EMPLOYER-SPONSORED DISABILITY INSURANCE: WHERE ARE THE GAPS IN COVERAGE?
}

\author{
Helen Levy \\ Working Paper 10382 \\ http://www.nber.org/papers/w10382 \\ NATIONAL BUREAU OF ECONOMIC RESEARCH \\ 1050 Massachusetts Avenue \\ Cambridge, MA 02138 \\ March 2004
}

This research was supported by the Department of Labor and the National Institute on Aging. The author thanks Vanessa Coca for excellent research assistance and Dan Beller, Tom DeLeire, Steve Donohue and Joseph Piacentini for very helpful comments. All programs and data used in this paper are available from the author on request. The views expressed herein are those of the author and not necessarily those of the National Bureau of Economic Research.

(C2004 by Helen Levy. All rights reserved. Short sections of text, not to exceed two paragraphs, may be quoted without explicit permission provided that full credit, including $(\mathbb{C}$ notice, is given to the source. 
Employer-Sponsored Disability Insurance: Where are the Gaps in Coverage?

Helen Levy

NBER Working Paper No. 10382

March 2004

JEL No. I10, J32

\title{
$\underline{\text { ABSTRACT }}$
}

I use data from the Current Population Surveys and Employee Benefits Surveys to analyze employer-sponsored disability insurance coverage. There does not appear to be a systematic trend from 1980 to 2000 in the fraction of workers with coverage. Disability insurance coverage rates are lower than health insurance coverage rates; low-skill, low-wage, low-tenure, part-time and small establishment workers are all less likely to have either of these fringe benefits. Public policy debates about workers without health insurance fail to consider an important economic risk these workers face in the event of an illness or injury: the risk of lost wages.

\author{
Helen Levy \\ Harris Graduate School of Public Policy Studies \\ University of Chicago \\ 1155 East 60th Street \\ Chicago, IL 60637 \\ and NBER \\ hlevy@uchicago.edu
}




\section{Introduction}

A great deal of public policy attention focuses on workers without health insurance coverage. Coverage by disability insurance - that is, insurance that replaces workers' wages in the event of a disability - receives far less attention, even though lost wages may represent a larger economic risk than medical bills for many workers. This risk may be especially large for low-wage, low-skill workers who are eligible for public health insurance but who have fewer resources to help provide for their other living expenses if they are disabled.

This paper analyzes trends in rates of coverage by private employer-sponsored disability coverage and compares the determinants of this coverage at a point in time to the determinants of employer-sponsored health insurance coverage. I find little evidence that there is a systematic trend from 1980 to 2000 in the fraction of workers with either short or long-term disability insurance, although changes in the data collection methods make it difficult to know this with confidence. I find that in 1993, rates of coverage among workers by short and long-term disability insurance are lower than the rate of coverage by employer-sponsored health insurance. I also find that the same worker and job characteristics that predict not having health insurance predict not having sick leave or long-term disability insurance. Specifically, low-skill, lowwage, low-tenure and part-time workers are all much less likely to have any of the three types of fringe benefits, as are workers in small establishments. Public policy debates that focus on workers without health insurance omit an important economic risk these workers face: specifically, the risk of lost wages in the event of an illness or injury.

\section{What Is Disability Insurance?}

Many public and private insurance programs provide cash benefits to replace wages in the event that a worker is injured. The federal Disability Insurance (DI) program pays benefits to 
workers with disabilities that are expected to be long term (lasting at least one year) or to result in death; there is a five month waiting period before DI payments begin, and an additional two year waiting period for Medicare eligibility (Ways and Means Committee 2000). State Workers' Compensation programs generally provide cash benefits and pay medical expenses for workers with short or long-term disabilities that result from work-related injuries. In 2000, 87.5 percent of all workers and 93.9 percent of wage and salary workers (i.e. those who were not selfemployed) were eligible for Worker's Compensation (National Academy of Social Insurance 2002). Thus, public programs replace at least some wages lost due to injuries that are either longterm or work-related, but provide no insurance against wages lost because of short-term injuries and illnesses that are not work-related.

One function of private disability insurance is therefore to replace earnings for workers with disabilities not covered by public insurance. Another is to provide supplemental income in case of long-term or work-related disabilities that are covered by public insurance, since replacement rates for DI and Workers' Compensation are generally well below $100 \%$. There is a great deal of variation in the specifics of employer-provided disability insurance, but generally it falls into the following three categories: ${ }^{1}$

- Sick leave: Paid time off while recovering from a temporary injury or illness that is not work-related.

- Short-term disability insurance: Partial salary replacement for a short period, usually 6 to 12 months.

- Long-term disability insurance: Cash benefits for workers with disabilities that are not work-related. There is usually a waiting period of 3 to 6 months before benefits begin;

\footnotetext{
${ }^{1}$ The discussion of types of private disability benefits is condensed from Department of Labor Bulletin 2517, p. 24.
} 
benefits may continue until retirement, until a predetermined age, or for a set number of months.

Clearly, the lines between these categories are not sharply drawn. In practice, within a firm, there may be important institutional differences involved in receiving benefits from one program or the other. For example, "calling in sick" (an example of the first type of insurance) typically requires very little paperwork whereas receiving short-term disability insurance benefits may be much more complicated. There may also be important differences in the assumption of risk across different plans; as is the case with health insurance, some employers choose to selfinsure while others will contract with an insurance company. An employer might also make different choices about self-insuring for different types of insurance; for example, self-insuring a short-term disability insurance plan but purchasing commercial long-term disability insurance. An employer might also not offer benefits at all; with the exception of New York, New Jersey and Hawaii, all of which mandate or sponsor temporary (i.e. short-term) disability insurance plans, these plans are voluntarily provided (or not) by employers. ${ }^{2}$ Workers may also purchase individual disability insurance policies directly from insurance companies.

Private employer-sponsored disability insurance is only one of many mechanisms for insuring workers against the risk of lost earnings because of disability, and some of the distinctions between it and other types of insurance contracts may seem arbitrary. Nonetheless, there are at least two reasons to focus on this segment of the market. First, it is provided as a distinct and recognizable feature of many employment contracts and is measured by surveys collecting data on fringe benefits. Second, it is the wage-replacement analogue of private employer-sponsored health insurance. That is, in a situation where medical bills would be paid

\footnotetext{
${ }^{2}$ The Family and Medical Leave Act (FMLA) of 1993 requires establishments with 50 or more workers to provide unpaid leave for specified purposes including illness or injury. For details, see Ruhm (1997) and Waldfogel (2001).
} 
by private employer-sponsored health insurance, lost earnings would be replaced by private employer-sponsored disability insurance. Lost wages may represent a larger economic risk than high medical bills. More than half of Workers' Compensation benefits are paid to replace wages rather than for medical care costs (Williams 2003). Policy concern about "the uninsured" typically focuses on individuals without health insurance coverage, but might just as well focus on individuals without disability insurance coverage.

\section{Data on private employer-sponsored disability insurance}

The data to be used are microdata from the April 1993 Employee Benefits Supplement to the CPS, microdata from the basic monthly CPS's from 1980 - 1999, and published data from the Department of Labor's Employee Benefits Surveys.

\section{The Employee Benefits Surveys}

The Bureau of Labor Statistics (BLS) has conducted the Employee Benefits Surveys more or less annually since 1980 . The first survey in 1980 included 1,509 medium and large private firms. "Medium and large" was defined as having more than 50, 100 or 250 employees depending on the industry. With the exception of 1987, similar surveys were conducted annually through 1989. The definition of "medium and large" was standardized across industries as of the 1988 survey to include establishments with at least 100 workers. Beginning in 1990, the Employee Benefits Surveys have covered small establishments (less than 100 workers) in even years and medium and large establishments in odd years. There have also been periodic surveys of state and local governments. 
The EBS asks establishments about benefits provided on a sample of jobs within the establishment. ${ }^{3}$ The EBS asks about sick leave (paid time off, for short periods), short-term disability insurance (called "accident and sickness insurance" prior to the 1995 survey) and longterm disability insurance, among other benefits. The BLS publishes summary statistics on the fraction of jobs with different benefits annually; the EBS data in this paper are taken from these published bulletins.

There are two changes to the EBS that make it difficult to interpret trends over time in EBS data on disability insurance. The first is the 1988 change in scope mentioned above (see Bulletin 2336, p. iii for details). The second is a change in the definitions of "paid sick leave" and what was called "sickness and accident insurance" prior to 1995 and is called "short-term disability insurance" beginning in 1995. As shown in Appendix Exhibit 1, the change in definition means that unfunded per-disability plans were considered "paid sick leave" prior to 1995 and considered "short-term disability insurance" in 1995 and later.

Also in 1995, the EBS publications no longer provide detailed information on what fraction of jobs have sick leave only, short-term disability insurance only, either, or both; instead, the published data say only what fraction of jobs have any sick leave and what fraction have any short-term disability insurance. It is possible to use the detailed data in the pre-1995 years to construct what should, in theory, be a comparable fraction of jobs with any sick leave or any disability insurance by adding detailed categories; but since this construction occurs at the same time that the definition of the two quantities changed as described above, the data should not be viewed as providing a consistent trend before and after 1995.

\footnotetext{
${ }^{3}$ For more details on the design of the EBS, please see Department of Labor (1995).
} 


\section{The Basic Monthly Current Population Surveys}

The second component of the analysis relies on data from the basic monthly CPS from 1980 through 2000, which asks about labor force activity in the week prior to the survey, including whether the respondent missed work because of illness and if so, whether the respondent was paid for the time off. This question sequence changed in 1994; Appendix Exhibits 2 and 3 summarize the relevant pre-1994 and 1994 and later questions. From 1980 through 1993, respondents were asked what their "major activity" had been in the previous week. Those who report that they did not work at all, but had a job from which they were temporarily absent are asked why they were absent. If the reason is illness, vacation, weather or a labor dispute, they are asked whether they received wages or salary for any of the time off the previous week. This allows me to identify workers who missed work because of illness, with or without pay. This measure does not capture individuals who are so disabled that they do not work at all, nor does it capture a worker who (for example) missed a day of work because of illness but nonetheless reported that his/her "major activity" in the prior week had been working. This measure of the probability of missing work due to illness therefore misses both very serious and very minor work disabilities; nonetheless, it is possible to estimate what fraction of workers experienced a disruption to their "major activity" of working because of illness, and whether they were paid for this time off.

Beginning in 1994, respondents are asked simply whether they worked at all in the week prior to the survey. If they say no, they are asked whether they had a job from which they were absent; if they were absent from a job, they are asked why they were absent and whether they were paid for any of the missed time. Therefore it is possible to construct similar measures of the fraction of workers who missed work due to illness, and the fraction of that group who were 
paid. It is likely that the change in the question sequence affects the responses, however, so the data should not be viewed as a consistent time series before and after 1994.

\section{The April 1993 CPS Supplement on Employee Benefits}

The April 1993 CPS included a supplement on employee benefits that was administered to about 26,000 workers. The supplement includes questions on non-wage benefits including disability insurance, sick leave, pensions, and health insurance, as well as job characteristics such as firm size, establishment size, industry, occupation, and the worker's tenure on the job. The questions about sick leave and disability insurance are presented in Appendix Exhibit 4. It is possible to determine whether a worker has any sick leave/short-term disability insurance; if the worker has any, the number of months for which wages would be replaced; and whether the worker has long-term disability insurance coverage.

\section{Results}

\section{A. Trends over time}

\section{The Employee Benefits Surveys}

Table 1 shows trends over time in the fraction of employees with sick leave, short-term disability insurance and long-term disability insurance. As discussed above, changes in the scope of the survey (1988) and in the definitions (1995) mean that these data are not a consistent time series; nonetheless, the data reveal some interesting patterns. Starting with long-term disability insurance, which has been defined relatively consistently throughout this period, it appears that the fraction of jobs with this benefit in medium and large establishments has remained fairly constant from 1980 to 1997 , fluctuating slightly just above forty percent. During 
the early 1980s there was an increase in the fraction of jobs with long-term disability insurance, from 40 percent in 1980 to 48 percent in 1986 . The drop to 42 percent in 1988 may be because of the change in the scope of the survey.

Most jobs in medium and large establishments have either sick leave or disability insurance; the fraction is constant at about 93 percent from 1980 to 1986 , then drops to 89 percent in 1988, though this drop most likely is due to the change in the scope of the survey. It is also interesting to note the differences in benefits for employees of small establishments versus those in medium and large establishments. Both short-term and long-term disability insurance are more common for employees of medium and large establishments than for employees of small establishments. About half of all employees of medium and large establishments have short-term disability insurance, while among employees of small establishments the fraction is about 29 percent. Small establishment employees are also much less likely to have long-term disability insurance (around 20 percent compared to around 40 percent for employees of medium and large establishments). The fraction with sick leave seems to be more similar in the different types of establishments, with half of all small establishment employees and slightly more than half (56 percent in 1997) of employees of medium and large establishments having sick leave.

Overall, the EBS data suggest that sick leave is a very common benefit in medium and large establishments, and slightly less common though still widespread in small establishments. Short and long-term disability insurance are not as common, covering 40 to 50 percent of jobs in medium and large establishments and about 20 to 30 percent of jobs in small establishments. 


\section{The Basic Monthly Current Population Surveys}

Table 2 shows the probability that a private-sector wage and salary worker in the basic monthly CPS reports that in the week prior to the survey s/he missed work because of illness (as described above - referred to from now on as "being out sick"), and the probability that this absence was paid, from 1980 to 2000 . Overall during this period, the probability of being out sick is 0.8 percent; about 43 percent of workers who were out sick received at least some pay during the time out. It appears that the change in the wording of the question resulted in many more people reporting being out sick, since the fraction jumps from 0.4 percent in 1993 and the two preceding years to almost 0.9 percent in $1994 .{ }^{4}$ There is no evidence of a systematic trend in the probability that a worker is out sick. Similarly, there is a discrete jump in 1994 in the probability that a worker who reported being out sick also reported being paid, from about 38 percent in 1993 to 41 percent in 1994; this too is most likely the result of changes in the questionnaire rather than an actual change between 1993 and 1994 in the probability that a worker who was out sick was paid.

\section{B. Determinants of disability and health insurance coverage in 1993}

In order to say more about which types of workers are likely to have sick leave, disability insurance, and health insurance, I analyze data from the April 1993 CPS Supplement on Employee Benefits. Table 3, columns 2 through 6 present the distribution of the number of months for which a worker would be paid at least some wages if s/he "got sick tomorrow and couldn't go to work for six months," by various worker and job characteristics. Overall, half of all workers would get no pay in this situation. Among those who would receive some pay, about

\footnotetext{
${ }^{4}$ An alternative possibility is that the FMLA resulted in an increase in actual work absence. It is not possible to use these data to evaluate whether this is true; though it is worth noting that if this were the case, one would expect the probability of being paid conditional on being out sick to have gone down, which it did not.
} 
a third (17.6 percent of all workers) would be paid for only one month and another third would be paid for 5-6 months. Forty-three percent of all workers report having long-term disability insurance coverage on their job, as shown in column 7 of Table 3. Both of these benefits are less prevalent than employer-sponsored health insurance, which 56.3 percent of these workers have, as shown in column 8 of Table $3 .^{5}$ Moreover, workers who have one benefit are more likely to have the others. Seventeen percent of workers without health insurance have sick leave and only about 12 percent have long-term disability insurance, while among workers with health insurance the corresponding rates are 77 percent and 67 percent.

All three benefits are much more prevalent for highly educated workers. Only about 20 percent of workers with less than a high school education have any sick leave or have long-term disability insurance, and only 31.4 percent of them have employer-sponsored health insurance. By contrast, two-thirds of workers with a college degree have sick leave, 56 percent have longterm disability insurance and three-quarters have health insurance.

Interestingly, black workers are slightly more likely than white workers to have either sick leave or long-term disability benefits, and are just as likely to have health insurance. Men are slightly less likely on average than women to have any sick leave (48 percent versus 52 percent), but are more likely to have long-term disability insurance (47 percent of men versus 39 percent of women) or health insurance (60 percent of men versus 52 percent of women). Single parents, whether male or female, are less likely than their single counterparts without children to have any of the three benefits.

Very young workers (25 years old or less) and older workers (65 and older) are far less likely to have jobs with any of the three benefits than are prime-aged (26 to 64 years old)

\footnotetext{
${ }^{5}$ Note that this is the fraction of workers who are policyholders, not the fraction covered by any employer-sponsored health insurance (including coverage as a dependent), which would be higher.
} 
workers. Among workers of prime age the only group for whom benefits differ by age is those close to retirement; workers ages 55 to 64 are slightly less likely than workers ages 26 to 54 to have any of the three benefits, although they are still more likely to do so than are very young or older workers.

Full-time workers are far more likely than part-time workers to have each of the three benefits. ${ }^{6}$ Three-quarters of full-time workers have some sick leave, compared to less than onequarter of part-time workers. Almost sixty percent of full-time workers have long-term disability insurance, compared to about one-sixth of part-time workers. This full-time/part-time differential is comparable to the one for health insurance ( 74 percent of full-time workers versus only 22 percent of part-time workers). There is also a strong differential with respect to the number of years the worker has held the job; three-quarters of workers who have been on the job less than a year have no sick leave, less than a quarter have long-term disability insurance, and only 29 percent have health insurance. Among workers on the job for more than ten years, just over two-thirds have sick leave, 59 percent have long-term disability insurance and threequarters have health insurance. Unionized workers are also far more likely to have any of the three benefits. $^{7}$

The probability of each of the three benefits increases with hourly wage; more than 80 percent of workers in the top fifth of the distribution of hourly wages have sick leave, 72 percent have long-term disability insurance, and 86 percent have health insurance. By contrast, only 15 percent of workers in the bottom fifth of the wage distribution have any sick leave, 13 percent have long-term disability insurance, and 19 percent have health insurance.

\footnotetext{
${ }^{6}$ See Farber and Levy (2000) for a detailed discussion of how the probability of having health insurance varies with full-time/part-time status and job tenure.

${ }^{7}$ See Buchmueller et al. (1999) for a discussion of the effect of unionization on the provision of health insurance.
} 
Provision of all three fringe benefits is also strongly related to firm and establishment size. By sector, public employees are most likely to have each type of benefit, followed by private sector wage and salary workers; self-employed workers are least likely to have any of the three. Only 14 percent of the self-employed have long-term disability insurance and only 21 percent have health insurance. There is also considerable variation across industry and occupation.

Table 4 presents the results of multivariate linear regressions that include most of these variables in order to determine which ones are of independent significance. These regressions are estimated using only private-sector wage and salary workers; each model also includes a full set of state dummies that are always jointly significant but are not reported in Table 4. I estimate four separate models: a linear probability model with dependent variable equal to one if the worker reports having any sick leave; an OLS regression using workers with sick leave only where the dependent variable is the number of months $(<1,1-2,3-4,5-6)$ of wage replacement the worker would receive; a linear probability model with dependent variable equal to one if the worker reports having long-term disability insurance; and a linear probability model with dependent variable equal to one if the worker reports having health insurance.

The regression results generally confirm the differentials described in the two-way table. There are some exceptions; there is no significant black-white health insurance differential, for example, in the multivariate analysis and the effect of age on the probability of benefits is not as straightforward as it appeared in the simple table. But generally, the regression results confirm that highly educated, highly paid workers, full-time workers, unionized workers, and workers who have been on the job a long time are more likely, all else equal, to have benefits. This is as 
true for sick leave and long-term disability insurance as it is for health insurance. In other words, workers on jobs without health insurance are also unlikely to have disability insurance.

\section{Implications and directions for future research}

The main findings of this analysis are first, that there does not seem to be a clear trend in rates of private disability insurance coverage and second, that workers who do not have health insurance are also unlikely to have disability insurance. What do these results suggest for public policy? The lack of a trend suggests that in contrast to the market for employer-sponsored health insurance, there is no cause for concern that private disability insurance coverage is eroding over time.

The fact that workers without health insurance are also likely to lack disability insurance is more troubling. A great deal of policy attention focuses on "the uninsured" - meaning individuals without health insurance - and particularly on uninsured workers. This concern is presumably motivated by a desire to buffer the economic consequences of illness or injury, which are of course not limited to medical bills. If a family lacks both health insurance and disability insurance, it is not clear whether medical bills or lost earnings represent a greater risk to their economic security. On one hand, medical bills may be many times larger than total family income while the lost earnings of one family member must by definition be less than this. On the other hand, there are multiple sources of "charity" medical care, including defaulting on debts to hospitals that are legally required to provide necessary medical care without advance payment, while the same may not be true for rent, food, clothing, and many other necessities. Further research is necessary to determine whether medical bills or lost earnings represent a 
larger economic risk to uninsured households. In the meantime, the results in this paper suggest that lack of disability insurance is another important dimension of being "uninsured". 


\section{References}

Buchmueller, Thomas, Robert G. Valletta and John DiNardo. 1999. Union Effects on Health Insurance Provision and Coverage. Unpublished manuscript.

Committee on Ways and Means, U.S. House of Representatives. 2000. The Green Book: Background Material and Data on Programs within the Jurisdicition of the Committee on Ways and Means. Available online at: http://aspe.hhs.gov/2000gb/

Farber, Henry and Helen Levy. 2000. Recent Trends in Employer-Sponsored Health Insurance: Are Bad Jobs Getting Worse? Journal of Health Economics 19: 93 - 119

National Academy of Social Insurance. 2002. "Workers' Compensation Coverage by State." Workers' Compensation Fact Sheet Number 1, October.

Ruhm, Christopher. 1997. Policy Watch: The Family and Medical Leave Act. Journal of Economic Perspectives 11(3): 175-186.

U.S. Department of Labor. 1981. Employee Benefits in Industry, 1980. Bureau of Labor Statistics Bulletin 2107.

U.S. Department of Labor. 1982. Employee Benefits in Medium and Large Firms, 1981. Bureau of Labor Statistics Bulletin 2140.

U.S. Department of Labor. 1983. Employee Benefits in Medium and Large Firms, 1982. Bureau of Labor Statistics Bulletin 2176.

U.S. Department of Labor. 1984. Employee Benefits in Medium and Large Firms, 1983. Bureau of Labor Statistics Bulletin 2213.

U.S. Department of Labor. 1985. Employee Benefits in Medium and Large Firms, 1984. Bureau of Labor Statistics Bulletin 2237.

U.S. Department of Labor. 1986. Employee Benefits in Medium and Large Firms, 1985. Bureau of Labor Statistics Bulletin 2262.

U.S. Department of Labor. 1987. Employee Benefits in Medium and Large Firms, 1986. Bureau of Labor Statistics Bulletin 2281.

U.S. Department of Labor. 1989. Employee Benefits in Medium and Large Firms, 1988. Bureau of Labor Statistics Bulletin 2336.

U.S. Department of Labor. 1990. Employee Benefits in Medium and Large Private Establishments, 1989. Bureau of Labor Statistics Bulletin 2363. 
U.S. Department of Labor. 1993. Employee Benefits in Medium and Large Private Establishments, 1991. Bureau of Labor Statistics Bulletin 2422.

U.S. Department of Labor. 1994. Employee Benefits in Medium and Large Private Establishments, 1993. Bureau of Labor Statistics Bulletin 2456.

U.S. Department of Labor. 1998. Employee Benefits in Medium and Large Private Establishments, 1995. Bureau of Labor Statistics Bulletin 2496.

U.S. Department of Labor. 1999. Employee Benefits in Medium and Large Private Establishments, 1997. Bureau of Labor Statistics Bulletin 2517.

U.S. Department of Labor. 1991. Employee Benefits in Small Private Establishments, 1990. Bureau of Labor Statistics Bulletin 2388.

U.S. Department of Labor. 1994. Employee Benefits in Small Private Establishments, 1992. Bureau of Labor Statistics Bulletin 2441.

U.S. Department of Labor. 1996. Employee Benefits in Small Private Establishments, 1994. Bureau of Labor Statistics Bulletin 2475.

U.S. Department of Labor. 1999. Employee Benefits in Small Private Establishments, 1996. Bureau of Labor Statistics Bulletin 2507.

U.S. Department of Labor. 1995. Employee Benefits Survey: A BLS Reader. Bureau of Labor Statistics Bulletin 2459.

Waldfogel, Jane. 2001. Family and medical leave: evidence from the 2000 Surveys. Monthly Labor Review, September, 17-23.

Williams, Cecili Thompson, Virginia P. Reno, and John F. Burton Jr. 2003. "Workers' Compensation: Benefits, Coverage and Costs 2001." National Academy of Social Insurance: http://www.nasi.org/usr_doc/Workers_Comp_Report_2001_Final.pdf 
Table 1

Prevalence of Sick Leave and/or Disability Insurance

Employee Benefits Surveys, 1980 - 1997

Fraction of workers with:

\begin{tabular}{lllllll}
\hline$(1)$ & $(2)$ & $(3)$ & $(4)$ & $(5)$ & $(6)$ & $(7)$ \\
\hline
\end{tabular}

Sick

Sick

leave or Sick Disability leave and Any Any disability leave insurance disability sick disability insurance only only insurance leave insurance LTD

\begin{tabular}{|c|c|c|c|c|c|c|c|}
\hline \multicolumn{8}{|c|}{ Medium and large establishments: } \\
\hline 1980 & 0.93 & 0.39 & 0.30 & 0.24 & 0.63 & 0.54 & 0.40 \\
\hline 1981 & 0.93 & 0.42 & 0.27 & 0.24 & 0.66 & 0.51 & 0.41 \\
\hline 1982 & 0.93 & 0.43 & 0.26 & 0.24 & 0.67 & 0.50 & 0.43 \\
\hline 1983 & 0.94 & 0.45 & 0.27 & 0.23 & 0.68 & 0.50 & 0.45 \\
\hline 1984 & 0.94 & 0.43 & 0.27 & 0.24 & 0.67 & 0.51 & 0.47 \\
\hline 1985 & 0.93 & 0.42 & 0.26 & 0.25 & 0.67 & 0.51 & 0.48 \\
\hline 1986 & 0.94 & 0.46 & 0.24 & 0.25 & 0.71 & 0.49 & 0.48 \\
\hline $1988^{*}$ & 0.89 & 0.43 & 0.20 & 0.26 & 0.69 & 0.46 & 0.42 \\
\hline 1989 & 0.89 & 0.46 & 0.21 & 0.22 & 0.68 & 0.43 & 0.45 \\
\hline 1991 & 0.86 & 0.42 & 0.19 & 0.25 & 0.67 & 0.44 & 0.40 \\
\hline 1993 & 0.87 & 0.43 & 0.22 & 0.23 & 0.66 & 0.45 & 0.41 \\
\hline $1995^{* *}$ & & & & & 0.58 & 0.53 & 0.42 \\
\hline 1997 & *** & *** & $* * *$ & $* * *$ & 0.56 & 0.55 & 0.43 \\
\hline
\end{tabular}

Small establishments:

\begin{tabular}{|c|c|c|c|c|c|c|c|}
\hline 1990 & 0.59 & 0.33 & 0.12 & 0.13 & 0.46 & 0.25 & 0.19 \\
\hline 1992 & 0.64 & 0.36 & 0.10 & 0.16 & 0.52 & 0.26 & 0.23 \\
\hline 1994 & 0.61 & 0.35 & 0.11 & 0.15 & 0.50 & 0.26 & 0.20 \\
\hline $1996^{*}$ & & & & & 0.50 & 0.29 & 0.22 \\
\hline
\end{tabular}

Notes:

The contents of shaded cells have been calculated by adding published numbers. Shaded cells in column 5 are the sum of the contents of columns 2 and 4; shaded cells in column 6 are the sum of the contents of columns 3 and 4.

* The scope of the survey was expanded in 1988 so that data are not directly comparable before and after 1988 .

** The definitions changed in 1995 and later surveys so that the data are not comparable; please see the text for an explanation.

${ }^{* * *}$ This information was not collected in this year. 
Table 2

Fraction of workers who were out sick and probability that they were paid Private sector wage and salary workers

Basic Monthly Current Population Surveys, 1980 - 2000

\begin{tabular}{ccc}
\hline & & \\
& & \\
Total $($ out sick $)$ & P(paid, if out sick) \\
& 0.0080 & 0.4335 \\
1980 & 0.0056 & 0.3385 \\
1981 & 0.0057 & 0.3720 \\
1983 & 0.0060 & 0.4051 \\
1984 & 0.0057 & 0.3636 \\
1985 & 0.0057 & 0.3445 \\
1986 & 0.0060 & 0.3557 \\
1987 & 0.0056 & 0.3492 \\
1988 & 0.0057 & 0.3430 \\
1989 & 0.0057 & 0.3688 \\
1990 & 0.0052 & 0.3436 \\
1991 & 0.0042 & 0.3349 \\
1992 & 0.0040 & 0.3242 \\
1993 & 0.0040 & 0.3500 \\
1994 & 0.0040 & 0.3777 \\
1995 & 0.0089 & 0.4135 \\
1996 & 0.0082 & 0.4242 \\
1997 & 0.0081 & 0.4318 \\
1998 & 0.0080 & 0.4405 \\
1999 & 0.0079 & 0.4344 \\
2000 & 0.0078 & 0.4543 \\
\hline
\end{tabular}

Note: Survey questions changed in 1994. Please see text and appendix for details. 
Table 3

Probability of paid sick leave, long-term disability insurance and health insurance

By worker and firm characteristics: all workers (includes public sector and self-employed)

April 1993 Employee Benefits Supplement

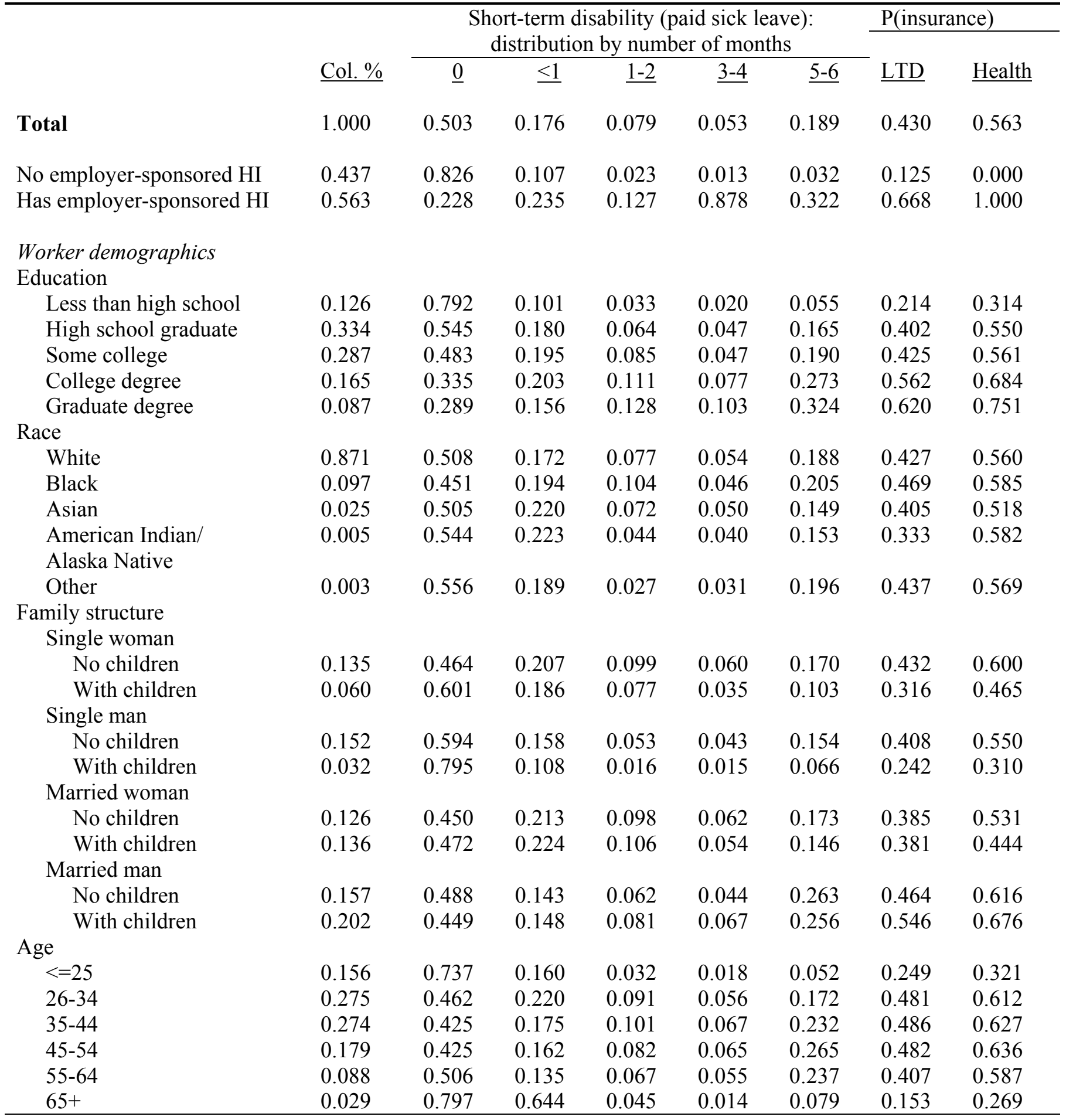


Table 3, continued

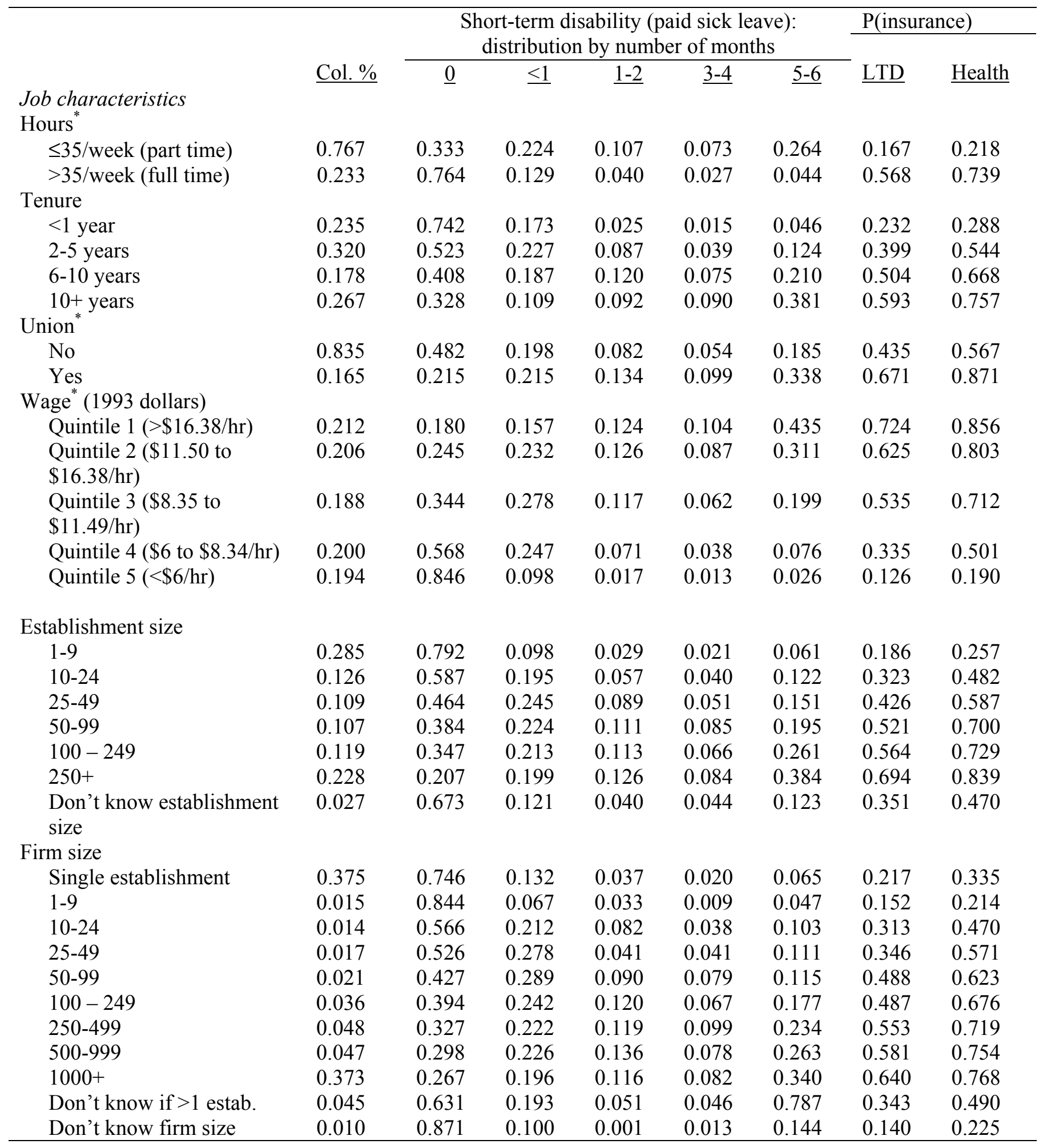


Table 3, continued

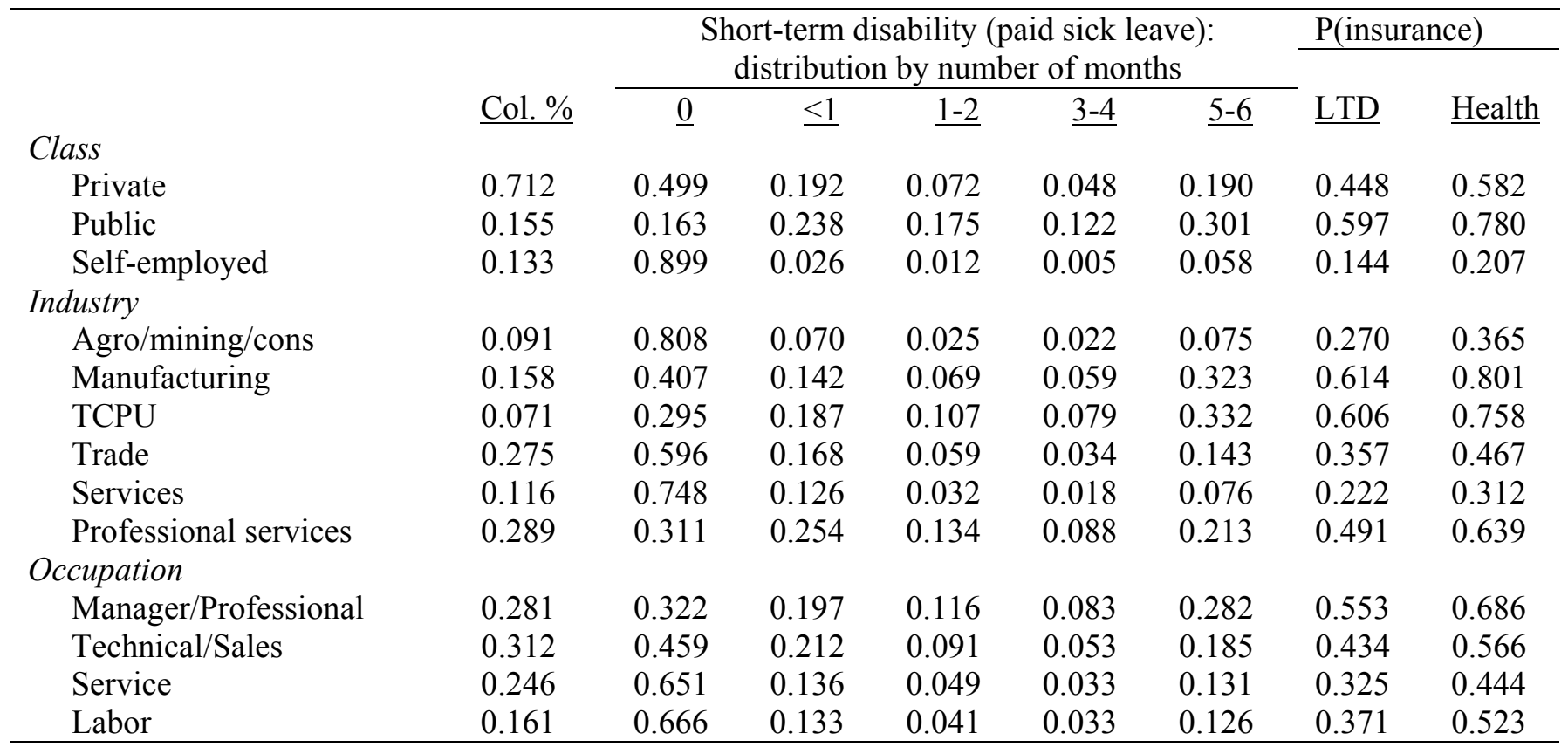

Sample size is 21,085 unless otherwise noted.

*Sample size for categories marked with an asterisk is 18,240 since these variables are not available for the 2,845 self-employed workers in the sample. 


\section{Table 4}

Determinants of coverage by sick leave, disability insurance and/or health insurance

Private sector wage and salary workers ages 20 - 64

April 1993 Employee Benefits Supplement

\begin{tabular}{|c|c|c|c|c|}
\hline \multirow[b]{2}{*}{ Independent Variables: } & \multicolumn{4}{|c|}{ Dependent variable: } \\
\hline & $\begin{array}{c}\text { Has paid sick } \\
\text { leave } \\
\text { (1) }\end{array}$ & $\begin{array}{l}\text { Duration of paid } \\
\text { sick leave } \\
\text { (2) }\end{array}$ & $\begin{array}{c}\text { Has long-term } \\
\text { disability insurance } \\
\text { (3) }\end{array}$ & $\begin{array}{l}\text { Has health } \\
\text { insurance from } \\
\text { employer } \\
\text { (4) }\end{array}$ \\
\hline High school graduate & $\begin{array}{c}0.0460 \\
(0.0121)\end{array}$ & $\begin{array}{l}-0.0893 \\
(0.0739)\end{array}$ & $\begin{array}{c}0.0285 \\
(0.0127)\end{array}$ & $\begin{array}{c}0.0414 \\
(0.0114)\end{array}$ \\
\hline Some college & $\begin{array}{c}0.0511 \\
(0.0130)\end{array}$ & $\begin{array}{l}-0.1732 \\
(0.0773)\end{array}$ & $\begin{array}{c}0.0246 \\
(0.0137)\end{array}$ & $\begin{array}{c}0.0396 \\
(0.0123)\end{array}$ \\
\hline College degree & $\begin{array}{c}0.0610 \\
(0.0156)\end{array}$ & $\begin{array}{l}-0.0181 \\
(0.0856)\end{array}$ & $\begin{array}{c}0.0639 \\
(0.0163)\end{array}$ & $\begin{array}{c}0.0603 \\
(0.0147)\end{array}$ \\
\hline Graduate degree & $\begin{array}{c}0.0136 \\
(0.0199)\end{array}$ & $\begin{array}{c}0.0710 \\
(0.0991)\end{array}$ & $\begin{array}{c}0.0634 \\
(0.0209)\end{array}$ & $\begin{array}{c}0.0457 \\
(0.0188)\end{array}$ \\
\hline Black & $\begin{array}{c}0.0438 \\
(0.0121)\end{array}$ & $\begin{array}{c}0.1349 \\
(0.0584)\end{array}$ & $\begin{array}{c}0.0236 \\
(0.0126)\end{array}$ & $\begin{array}{l}-0.0152 \\
(0.0114)\end{array}$ \\
\hline $\begin{array}{l}\text { American Indian/ } \\
\text { Alaskan Native }\end{array}$ & $\begin{array}{c}0.0246 \\
(0.0491)\end{array}$ & $\begin{array}{l}-0.0001 \\
(0.2548)\end{array}$ & $\begin{array}{l}-0.0129 \\
(0.0516)\end{array}$ & $\begin{array}{c}0.0439 \\
(0.0463)\end{array}$ \\
\hline Asian & $\begin{array}{c}0.0224 \\
(0.0228)\end{array}$ & $\begin{array}{l}-0.1928 \\
(0.1083)\end{array}$ & $\begin{array}{l}-0.0199 \\
(0.0239)\end{array}$ & $\begin{array}{c}0.0566 \\
(0.0215)\end{array}$ \\
\hline Other race & $\begin{array}{l}-0.0315 \\
(0.0644)\end{array}$ & $\begin{array}{c}0.1483 \\
(0.3066)\end{array}$ & $\begin{array}{l}-0.0489 \\
(0.0676)\end{array}$ & $\begin{array}{c}0.0246 \\
(0.0607)\end{array}$ \\
\hline Single woman, no kids & $\begin{array}{c}0.0818 \\
(0.0128)\end{array}$ & $\begin{array}{c}0.0718 \\
(0.0630)\end{array}$ & $\begin{array}{c}0.0217 \\
(0.0134)\end{array}$ & $\begin{array}{c}0.0414 \\
(0.0120)\end{array}$ \\
\hline Single woman, with kids & $\begin{array}{c}0.0401 \\
(0.0174)\end{array}$ & $\begin{array}{l}-0.1325 \\
(0.0892)\end{array}$ & $\begin{array}{l}-0.0045 \\
(0.0183)\end{array}$ & $\begin{array}{c}0.0192 \\
(0.0164)\end{array}$ \\
\hline Single man, with kids & $\begin{array}{l}-0.0315 \\
(0.0243)\end{array}$ & $\begin{array}{l}-0.1251 \\
(0.1443)\end{array}$ & $\begin{array}{c}0.0022 \\
(0.0255)\end{array}$ & $\begin{array}{l}-0.0420 \\
(0.0229)\end{array}$ \\
\hline Married woman, no kids & $\begin{array}{c}0.0631 \\
(0.0138)\end{array}$ & $\begin{array}{l}-0.1406 \\
(0.0667)\end{array}$ & $\begin{array}{l}-0.0356 \\
(0.0144)\end{array}$ & $\begin{array}{l}-0.0712 \\
(0.0130)\end{array}$ \\
\hline Married man, no kids & $\begin{array}{c}0.0333 \\
(0.0132)\end{array}$ & $\begin{array}{l}-0.0791 \\
(0.0636)\end{array}$ & $\begin{array}{l}-0.0148 \\
(0.0138)\end{array}$ & $\begin{array}{l}-0.0248 \\
(0.0124)\end{array}$ \\
\hline Married woman w/kids & $\begin{array}{c}0.0454 \\
(0.0132)\end{array}$ & $\begin{array}{l}-0.1298 \\
(0.0661)\end{array}$ & $\begin{array}{l}-0.0343 \\
(0.0139)\end{array}$ & $\begin{array}{l}-0.1314 \\
(0.0125)\end{array}$ \\
\hline Married man w/kids & $\begin{array}{c}0.0196 \\
(0.0117)\end{array}$ & $\begin{array}{l}-0.0228 \\
(0.0576)\end{array}$ & $\begin{array}{c}0.0141 \\
(0.0123)\end{array}$ & $\begin{array}{l}-0.0231 \\
(0.0111)\end{array}$ \\
\hline
\end{tabular}


Table 4, continued

\begin{tabular}{|c|c|c|c|c|c|}
\hline \multirow{2}{*}{\multicolumn{2}{|c|}{ Independent Variables: }} & \multicolumn{4}{|c|}{ Dependent variable: } \\
\hline & & $\begin{array}{c}\text { Has paid sick } \\
\text { leave }\end{array}$ & $\begin{array}{l}\text { Duration of paid } \\
\text { sick leave }\end{array}$ & $\begin{array}{c}\text { Has long-term } \\
\text { disability insurance }\end{array}$ & $\begin{array}{l}\text { Has health } \\
\text { insurance from } \\
\text { employer }\end{array}$ \\
\hline \multirow[t]{8}{*}{ Age: } & $26-34$ & 0.0274 & 0.0135 & 0.0118 & 0.0368 \\
\hline & & $(0.0116)$ & $(0.0634)$ & $(0.0122)$ & $(0.0109)$ \\
\hline & $35-44$ & 0.0058 & 0.0115 & -0.0348 & -0.0052 \\
\hline & & $(0.0123)$ & $(0.0667)$ & $(0.0129)$ & $(0.0116)$ \\
\hline & $45-54$ & -0.0079 & -0.0241 & -0.0393 & -0.0187 \\
\hline & & $(0.0138)$ & $(0.0729)$ & $(0.0145)$ & $(0.0130)$ \\
\hline & $55-64$ & -0.0036 & 0.1364 & -0.0591 & -0.0090 \\
\hline & & $(0.0167)$ & $(0.0867)$ & $(0.0176)$ & $(0.0158)$ \\
\hline \multirow[t]{6}{*}{ Tenure: } & -5 years & 0.0838 & 0.0264 & 0.0609 & 0.1425 \\
\hline & & $(0.0092)$ & $(0.0510)$ & $(0.0097)$ & $(0.0087)$ \\
\hline & 10 years & 0.1307 & 0.2388 & 0.1057 & 0.2042 \\
\hline & & $(0.0113)$ & $(0.0574)$ & $(0.0119)$ & $(0.0107)$ \\
\hline & 10 years & 0.1657 & 0.4704 & 0.1618 & 0.2423 \\
\hline & & $(0.0119)$ & $(0.0588)$ & $(0.0125)$ & $(0.0112)$ \\
\hline \multirow[t]{10}{*}{ Establishment size: } & $10-24$ & 0.0466 & -0.0202 & 0.0282 & 0.0938 \\
\hline & & $(0.0117)$ & $(0.0660)$ & $(0.0123)$ & $(0.0110)$ \\
\hline & $25-49$ & 0.0817 & -0.0902 & 0.0776 & 0.1292 \\
\hline & & $(0.0128)$ & $(0.0676)$ & $(0.0135)$ & $(0.0121)$ \\
\hline & $50-99$ & 0.1005 & 0.0248 & 0.0991 & 0.1721 \\
\hline & & $(0.0132)$ & $(0.0664)$ & $(0.0139)$ & $(0.0125)$ \\
\hline & $00-249$ & 0.1349 & 0.0986 & 0.1296 & 0.2033 \\
\hline & & $(0.0131)$ & $(0.0643)$ & $(0.0138)$ & $(0.0123)$ \\
\hline & $250+$ & 0.1369 & 0.0858 & 0.1301 & 0.1784 \\
\hline & & $(0.0135)$ & $(0.0634)$ & $(0.0142)$ & $(0.0127)$ \\
\hline \multirow{2}{*}{\multicolumn{2}{|c|}{ Don't know estab. size }} & 0.0128 & 0.4601 & 0.0741 & 0.1149 \\
\hline & & $(0.0222)$ & $(0.1254)$ & $(0.0233)$ & $(0.0209)$ \\
\hline \multirow[t]{12}{*}{ Firm size } & $10-24$ & 0.0721 & -0.0603 & 0.0462 & 0.0659 \\
\hline & & $(0.0269)$ & $(0.1417)$ & $(0.0282)$ & $(0.0253)$ \\
\hline & $25-49$ & 0.0687 & -0.0354 & 0.0577 & 0.1224 \\
\hline & & $(0.0245)$ & $(0.1252)$ & $(0.0257)$ & $(0.0230)$ \\
\hline & $50-99$ & 0.1149 & -0.0739 & 0.1793 & 0.1139 \\
\hline & & $(0.0222)$ & $(0.1053)$ & $(0.0233)$ & $(0.0209)$ \\
\hline & $00-249$ & 0.0860 & 0.1799 & 0.0984 & 0.1028 \\
\hline & & $(0.0182)$ & $(0.0865)$ & $(0.0191)$ & $(0.0171)$ \\
\hline & $250-499$ & 0.1116 & 0.1288 & 0.1433 & 0.1111 \\
\hline & & $(0.0170)$ & $(0.0776)$ & $(0.0179)$ & $(0.0160)$ \\
\hline & $500-999$ & 0.1103 & 0.2143 & 0.1699 & 0.1377 \\
\hline & & $(0.0170)$ & $(0.0771)$ & $(0.0179)$ & $(0.0160)$ \\
\hline
\end{tabular}

Table continues on next page. 
Table 4, continued

\begin{tabular}{|c|c|c|c|c|c|}
\hline \multirow{2}{*}{\multicolumn{2}{|c|}{$\begin{array}{l}\text { Independent Variables: } \\
\text { Firm size (continued): }\end{array}$}} & \multicolumn{4}{|c|}{ Dependent variable: } \\
\hline & & $\begin{array}{c}\text { Has paid sick } \\
\text { leave }\end{array}$ & $\begin{array}{l}\text { Duration of paid } \\
\text { sick leave }\end{array}$ & $\begin{array}{c}\text { Has long-term } \\
\text { disability insurance }\end{array}$ & $\begin{array}{c}\text { Has health } \\
\text { insurance from } \\
\text { employer }\end{array}$ \\
\hline \multirow{2}{*}{\multicolumn{2}{|c|}{$1000+$}} & 0.1643 & 0.3890 & 0.2276 & 0.1373 \\
\hline & & $(0.0105)$ & $(0.0510)$ & $(0.0110)$ & $(0.0099)$ \\
\hline \multirow{2}{*}{\multicolumn{2}{|c|}{ Don't know if $>1$ estab. }} & 0.0557 & 0.2287 & 0.0833 & 0.0624 \\
\hline & & $(0.0167)$ & $(0.0919)$ & $(0.0175)$ & $(0.0157)$ \\
\hline \multirow{2}{*}{\multicolumn{2}{|c|}{ Don't know firm size }} & -0.0632 & -0.3915 & -0.0458 & -0.0873 \\
\hline & & $(0.0318)$ & $(0.2594)$ & $(0.0334)$ & $(0.0299)$ \\
\hline \multirow{2}{*}{\multicolumn{2}{|c|}{ Industry: Manufacturing }} & 0.1649 & 0.1595 & 0.0796 & 0.1613 \\
\hline & & $(0.0151)$ & $(0.0914)$ & $(0.0158)$ & $(0.0142)$ \\
\hline \multirow{2}{*}{\multicolumn{2}{|c|}{ TCPU }} & 0.2276 & -0.0927 & 0.0643 & 0.1133 \\
\hline & & $(0.0179)$ & $(0.0997)$ & $(0.0188)$ & $(0.0169)$ \\
\hline \multirow{2}{*}{\multicolumn{2}{|c|}{ Trade }} & 0.1629 & -0.1676 & 0.0239 & 0.0837 \\
\hline & & $(0.0148)$ & $(0.0915)$ & $(0.0155)$ & $(0.0139)$ \\
\hline \multirow{2}{*}{\multicolumn{2}{|c|}{ Services }} & 0.1234 & -0.1398 & -0.0205 & 0.0241 \\
\hline & & $(0.0164)$ & $(0.1029)$ & $(0.0172)$ & $(0.0155)$ \\
\hline \multirow{2}{*}{\multicolumn{2}{|c|}{ Professional services }} & 0.2766 & -0.3445 & 0.0183 & 0.0905 \\
\hline & & $(0.0159)$ & $(0.0935)$ & $(0.0167)$ & $(0.0150)$ \\
\hline \multirow[t]{12}{*}{ Occupation } & Tech./sales & -0.0151 & 0.0015 & 0.0057 & 0.0056 \\
\hline & & $(0.0103)$ & $(0.0446)$ & $(0.0108)$ & $(0.0097)$ \\
\hline & Service & -0.1239 & -0.0386 & -0.0458 & -0.0492 \\
\hline & & $(0.0120)$ & $(0.0580)$ & $(0.0126)$ & $(0.0113)$ \\
\hline & Labor & -0.1502 & -0.0716 & -0.0525 & -0.0405 \\
\hline & & $(0.0136)$ & $(0.0663)$ & $(0.0143)$ & $(0.0128)$ \\
\hline & Full time & 0.2096 & 0.1694 & 0.1636 & 0.2400 \\
\hline & & $(0.0097)$ & $(0.0584)$ & $(0.0102)$ & $(0.0091)$ \\
\hline & ourly worker & -0.0717 & -0.2517 & -0.0474 & -0.0335 \\
\hline & & $(0.0086)$ & $(0.0412)$ & $(0.0090)$ & $(0.0081)$ \\
\hline & nion member & 0.0328 & 0.1037 & 0.0306 & 0.0878 \\
\hline & & $(0.0119)$ & $(0.0537)$ & $(0.0125)$ & $(0.0112)$ \\
\hline \multicolumn{6}{|l|}{ Wage: } \\
\hline \multirow{2}{*}{\multicolumn{2}{|c|}{ Top quintile $(>16.38 / \mathrm{hr})$}} & 0.1460 & -0.0041 & 0.0849 & 0.1479 \\
\hline & & $(0.0113)$ & $(0.0769)$ & $(0.0119)$ & $(0.0107)$ \\
\hline \multirow{2}{*}{\multicolumn{2}{|c|}{ Q2 (\$11.50 to $16.38 / \mathrm{hr})$}} & 0.2257 & 0.0829 & 0.1825 & 0.2360 \\
\hline & & $(0.0125)$ & $(0.0774)$ & $(0.0131)$ & $(0.0118)$ \\
\hline \multirow{2}{*}{\multicolumn{2}{|c|}{ Q3 (\$8.35 to $\$ 11.49 / \mathrm{hr})$}} & 0.2600 & 0.2444 & 0.2217 & 0.2633 \\
\hline & & $(0.0133)$ & $(0.0794)$ & $(0.0139)$ & $(0.0125)$ \\
\hline \multirow{2}{*}{\multicolumn{2}{|c|}{ Q4 (\$6 to $8.34 / \mathrm{hr})$}} & 0.2698 & 0.3606 & 0.2732 & 0.2777 \\
\hline & & $(0.0149)$ & $(0.0848)$ & $(0.0156)$ & $(0.0140)$ \\
\hline \multirow{2}{*}{\multicolumn{2}{|c|}{ Intercept }} & -0.1937 & 2.4188 & -0.0811 & -0.1864 \\
\hline & & $(0.0250)$ & $(0.1581)$ & $(0.0262)$ & $(0.0235)$ \\
\hline Sample size: & & 13,681 & 7,907 & 13,681 & 13,681 \\
\hline
\end{tabular}

Note: all models also include a full set of state dummies. 
Figure 1

Fraction of workers who were out sick and probability that they were paid

Private sector wage and salary workers

Basic Monthly Current Population Surveys, 1980 - 2000

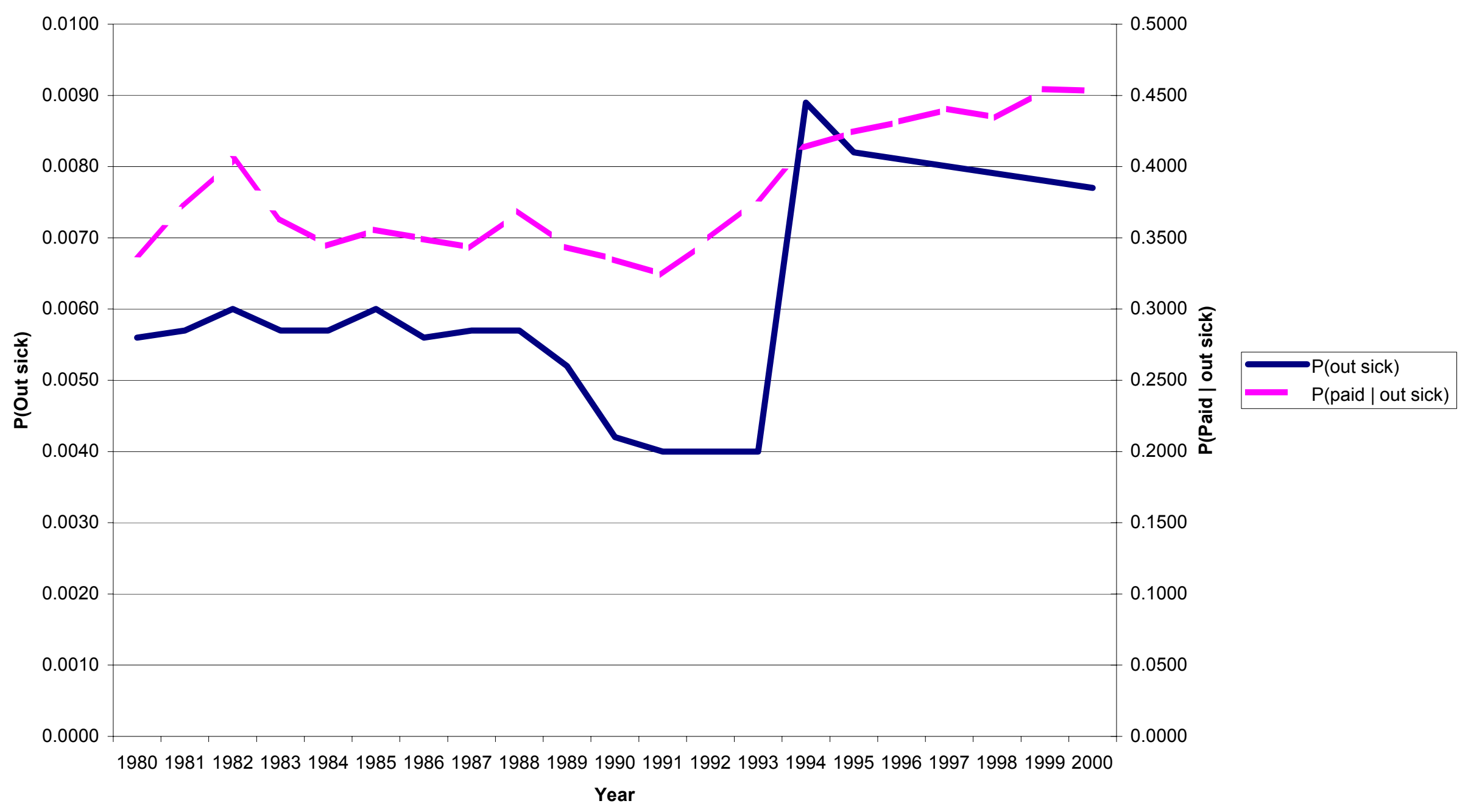

Note: Survey questions changed in 1994. Please see text and appendix for details. 
Appendix: Variable definitions and question sequences 
Appendix Exhibit 1

EBS definitions of sick leave, sickness and accident insurance, and short-term disability insurance

Old definitions (1980 - 1994):

Paid sick leave

Sickness and accident insurance

New definitions (since 1995):

Plans that specify a maximum number of days or unlimited days

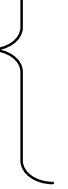

Unfunded per-disability plans

Insured, self-insured and mandated plans available per disability
Paid sick leave

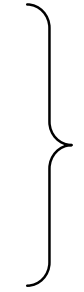

Short-term

disability insurance 


\section{Appendix Exhibit 2}

Current Population Survey Basic Monthly Surveys, 1980 - 1993

Question sequence on paid/unpaid absence from work, 1980 - 1993

19. What was doing most of last week?

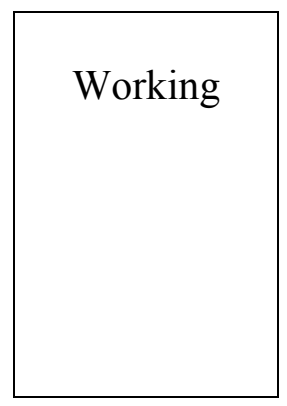

With a job, not at work
Looking for work
Keeping house
Going to school
Retired
Other

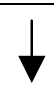

20. Did you do any work at all last week?

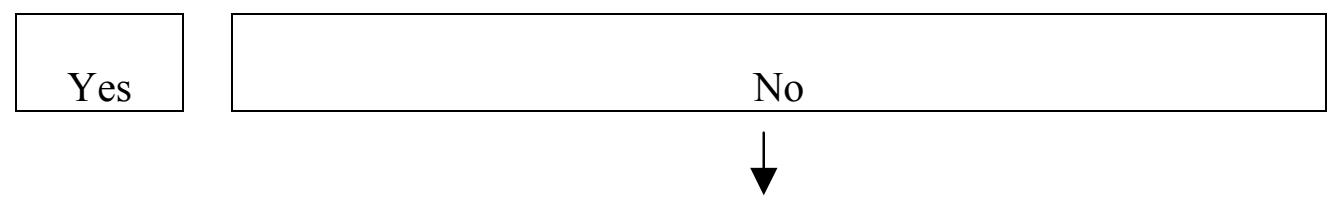

21. Were you absent from a job?

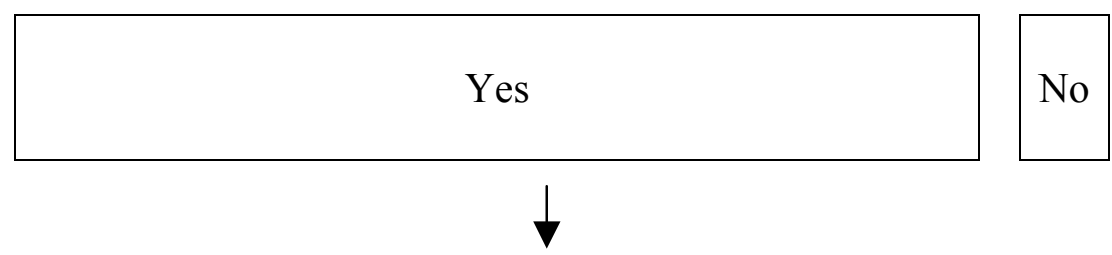

21A. Why were you absent?

\begin{tabular}{|l|l|}
\hline $\begin{array}{l}\text { Own illness } \\
\text { On vacation } \\
\text { Bad weather } \\
\text { Labor dispute }\end{array}$ & $\begin{array}{l}\text { New job begins w/in } 30 \text { days } \\
\text { Temporary layoff } \\
\text { Indefinite layoff } \\
\text { Other }\end{array}$ \\
\hline$\downarrow$
\end{tabular}

21B. Is receiving wage or salary from his/her employer for any of the time off LAST WEEK?

21C. Does usually work 35 hours or more a week at this job?

Unable to work 


\section{Appendix Exhibit 3}

Current Population Survey Basic Monthly Surveys, 1994 - 2000

Question sequence on paid/unpaid absence from work, 1980 - 1993

20. LAST WEEK, did you do ANY work for (either) pay (or profit)?

Yes

No

20B-a. LAST WEEK, (in addition to the business) did you have a job either full or part time? Include any job from which you were temporarily absent.

Yes

No

20B-1. What was the main reason (you/he/she)

(was/were) absent from work (THE WEEK BEFORE

\section{LAST/LAST WEEK)?}

On layoff (temporary or indefinite))

Slack work/business conditions)

Waiting for a new job to begin)

Vacation/personal days

Own illness/injury/medical problems

Child care problems

Other family/personal obligation

Maternity/paternity leave

Labor dispute

Weather affected job

School/training

Civic/military duty

Does not work in the business

Other (specify)

21B. (Are/Is) (you/he/she) being paid by (your/his/her) employer for any of the time off (the week before last/last week)?
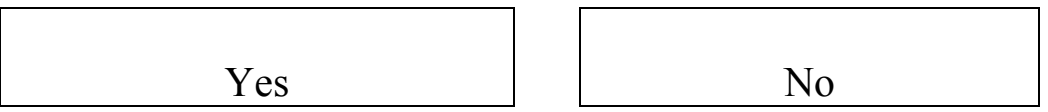


\section{Appendix Exhibit 4 \\ Current Population Survey April 93 Employee Benefits Supplement Question sequence on sick leave/sickness insurance}

The April 1993 Employee Benefits Supplement asks three questions relevant to sick leave and disability insurance:

A-S58: "On your job, do you get any paid sick leave or sickness insurance?"

$\begin{array}{lr}\text { Yes } & 14,071 \\ \text { No } & 11,344 \\ \text { Don't know } & 580 \\ \text { No response } & 86 \\ \text { Total: } & 26,081\end{array}$

If "yes" to question A-S58:

A-S59: "If you got sick tomorrow and couldn't go to work for six months, about how long during that time would you be paid any part of your wages?"

$\begin{array}{lr}<1 \text { month } & 4,204 \\ \text { 1-2 months } & 1,901 \\ \text { 3-4 months } & 1,252 \\ \text { 5-6 months } & 4,200 \\ \text { Don't know } & 2,471 \\ \text { No response } & 43 \\ \text { Total } & 14,071\end{array}$

A-S60: "If you had a long-term disability and could not return to work, would you get disability benefits from an insurance plan or pension plan on your job?"

$\begin{array}{lr}\text { Yes } & 9,569 \\ \text { No } & 13,069 \\ \text { Don't know } & 3,323 \\ \text { Missing } & 120 \\ \text { Total } & 26,081\end{array}$

